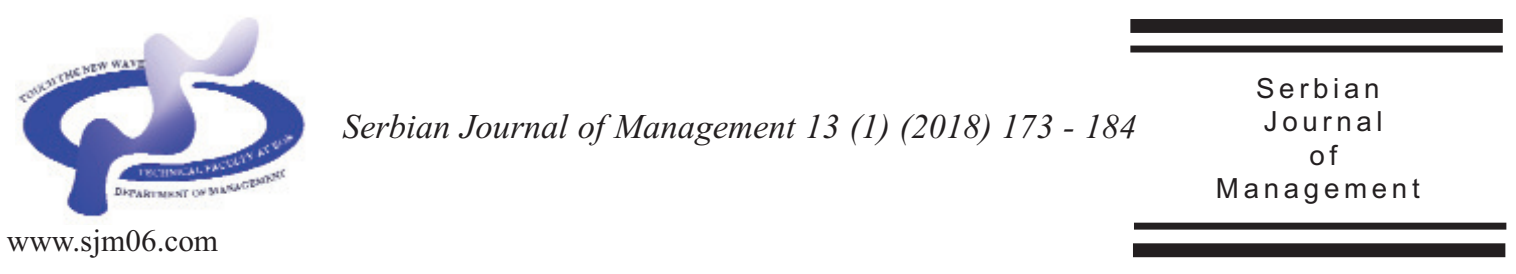

\title{
INVESTIGATING FACTOR INTERACTIONS IN FORMALISING THE PROCESS OF DEVELOPING NEW PRODUCTS
}

\author{
Bozhana Stoycheva* and Diana Antonova \\ "Angel Kanchev" University of Ruse, Faculty of Business and Management, \\ str. "Studentska" 8, 7017, Ruse, Bulgaria
}

(Received 31 January 2018; accepted 27 March 2018)

\begin{abstract}
The creation of new product development programmes in industrial organisations, as a process involves a system of activities for defining, planning and implementing projects, with a view to successful market realisation. The success of a programme and its associated projects is not unambiguous (depends to some extent on the participants' point of view) and can be related to the achievement of predetermined goals and constraints, customer satisfaction, organisational knowledge, etc. For the respective industrial company, the planning process is more important than the plan itself, because hypotheses are checked; comparable alternatives are analysed; the future consequences of one or another of today's decisions are investigated; the necessary changes to the prerequisites are made.

The survey was conducted in 560 medium and large enterprises operating in the manufacturing industry of Bulgaria. The aim is to establish independent factor variables and their value impacts on the effective management of the process of developing new products related to the dependent variable "formalisation or use of officially documented procedures describing the new product development (NPD) process".

In order to meet the target, a quantitative study was carried out by applying a correlation and regression analysis to search for relationships and dependences between the variables examined. A regression model is presented for the dependent variable studied. The results and recommendations obtained can be used to improve the management of the product innovation process.
\end{abstract}

Keywords: innovation process, new products development, formalisation of NPD, factor analysis

\footnotetext{
* Corresponding author: bstoycheva@uni-ruse.bg
}

DOI: $10.5937 / \mathrm{sjm} 13-16409$ 


\section{INTRODUCTION}

When viewing innovations, emphasis can be placed on their process nature - a set of interrelated but phased activities (Rametsteiner \& Weiss, 2006; Oliviera \& Rozenfeld, 2010; Riel et al., 2013; Albers et al., 2016). The subject of the innovation process is to give a specific form to the idea generated, which is then materialised in a new or improved product (commodity or service), the main goal being the innovation to reach the market and find successful realisation there, after it has passed through various phases (Belliveau et al., 2002; Chang et al., 2011; Geissdoerfer et al., 2017). Viewing the innovation as a process allows the conscious optimisation of its creation through improving the management, organisation, strategy employed, as well as specific methods and tools (Wang, 2009; Dickel \& Moura, 2016). According to this assumption, the specific roles and objectives of the participants in this process change at the different stages (Akgün et al., 2008; Artto \& Kulvik, 2011).

A number of studies and efforts of researchers have been directed to investigating the reasons for success or failure of the new products. The emphasis of research is targeted to the factors, leading to success in the development of an innovation, which provides a competitive advantage (Kulatunga et al., 2015; Suharyanti et al., 2015; Kohl et al., 2016). The field of effectively managing the process of developing new industrial products is also the subject of research since it can aid a more successful performance than that of the competitors (Hong \& Roh, 2009; Kim \& Kim, 2009; Sundström \& Zika-Viktorsson, 2009; Kazmi et al., 2016).

Previous similar studies in the USA
(Griffin, 1997; Barczak et al., 2009), Sweden (Rundquist \& Chibba, 2004; Rundquist \& Halila, 2010) and Malaysia (Al-Shalabi et al., 2008; Al-Shalabi \& Rundquist, 2010), related to measuring NPD success, identifying the practices and strategies employed in NPD, determining the state of the methods and tools used in NPD are the foundation for conducting similar research among Bulgarian industrial enterprises.

The subject of research is the innovation process in medium-sized and large Bulgarian industrial enterprises through studying the management of NPD process.

The object of research are medium-sized and large Bulgarian industrial enterprises, according to the criterion number of employees. In the National classificator of economic activities, these enterprises are registered in sector C "Processing industry" and deal with food production; production of timber and timber and cork products, except furniture; production of articles of straw and knitting materials; production of paper and cardboard, as well as articles from those materials; production of articles of rubber and plastics, as well as production of machines and equipment with general and specific purpose in Bulgaria.

The goal of this study is to investigate factors, influencing the effective management of the NPD process, including practices implemented for guidance and organisation of the innovation process, to research the structuring and formalising of this process, as well as the methods and tools applied, which lead to obtaining a competitive advantage, by determining factors that have an impact on the dependent variable "formalising of the NPD process or using officially documented procedures, describing this process".

In connection with the goal of this 
research to investigate factors which influence the effective management of the process of new product development, besides the dependent variable "Formalising the NPD process", two other dependent variables have been determined, namely, "Success of new products compared to the competitors" and "Success of the NPD programme". Similarly, impact factors have been investigated with the purpose to obtain statistically significant correlations, also pointing the individual impact of each independent variable studied.

The goal is to combine the factors influencing the dependent variables and to present a generalised basic model, which has an impact on the successful management of NPD process and can be tested in practice. Influencing factors in the proposed baseline model combine the factors influencing variables are verified by expert evaluations, the purpose of which is to finally confirm or reject the model to be approved.

The results obtained and the "An attributed model of factors influencing the success of NPD process management", influencing the management process of developing new products in Bulgarian industrial enterprises will be the object of future publications.

Objectives of the present paper:

1. To identify factors with an impact on the formalising of the NPD process.

2. To present the general and individual impact of each factor on the formalising of the NPD process.

The questionnaire used in Bulgaria is based on indexes already tested, which have been adapted to the Bulgarian industrial enterprises. The survey card used for the comparative survey has been developed by Product Development and Marketing
Association (PDMA) conducted in 2003. Using the modules from the PDMA, a survey has been done with the express written consent of A. Griffin. This questionnaire for investigating the NPD process contains a cover letter and 6 parts: (I) "General questions about the company"; (II) "Common process of NPD"; (III) "Management of innovation products portfolio"; (IV) "Processes of product development through outsourcing"; (V) "Organisation of NPD"; (VI) "Methods and tools for NPD".

The questionnaire addresses the whole company and not just a single business unit. The total number of sub-questions which are part of the survey is 253 . The questionnaire consists of both open (76), and closed answers (177), some of which are presented as tables with evaluation scales.

Answers have been obtained from preselected target respondents, representing a circle of people, who are widely aware of the overall activity of the respective organisation: executive director or manager, brand manager, R\&D manager. If there is not such a position, the questionnaire is filled in by an expert, responsible for NPD.

The organisations surveyed are 234 out of 559 , which meet the criteria of the survey or the activity level of the sample is $63 \%$. The results are statistically significant, both for each part and for the general population.

\section{CONCEPTUAL FRAMEWORK}

One of the success factors in NPD is the formalising of the process of innovation development. The aim of the survey is to identify the factors, which affect this result variable to the highest degree. In order to achieve this aim, a preliminary testing of the 
correlations of all factor variables from the survey questions with the dependent variable "Formalising of the NPD process" has been conducted with the purpose of identifying statistically significant relationships.

\subsection{Correlation analysis of the} dependent variable "Formalising of the NPD process"

In this paper, to establish correlations between the variables, the most commonly applied measure correlation coefficient of Pearson $(r)$ is used for the connection and relationship between the two variables.

As a result of the correlation analysis conducted, factors of statistically significant correlation, connected to the dependent variable "Formalising the NPD process" have been derived. Twenty two impact factors have been identified, referring to the basic survey modules, as follows:

1. Factors, related to the company profile

- A significant direct relation between new product success compared to that of competitors and formalising the NPD process (corrcoef $r=0.518$ );

- A moderate direct relation between technical support for the NPD programme and the process of its formalising (corrcoef $r=0.341)$;

- The success of the NPD programme is directly related to the formalisation of the process for its implementation (corrcoef $r=0.357)$.

2. A factor, related to the innovation portfolios management

- Implementing a Specific strategy for new product activities that directs and integrates the entire new product development process is in a moderate direct relation to formalising the process of NPD (corrcoef $r=0.436$ ).

\section{Factors, related to NPD organisation}

- Manufacturing Managers support for innovation that guarantees staff's active and effective participation leads to a more significant formalisation of NPD process (corrcoef $r=0.308)$;

- Senior managers' support for innovation by ensuring structures, processes, and other organisational mechanisms leads to a more significant formalisation of NPD process (corrcoef $r=0.310$ );

- Senior managers' support for the smooth flow of available resources to innovation projects leads to a more significant formalisation of NPD process (corrcoef $r=0.315$ ).

\section{Factors, related to methods and tools} for NPD employed

The impact of methods and tools for NPD on formalising the process of NPD is the strongest. Fifteen impacts in direct moderate correlation to the dependent variable studied have been identified:

- market research tools/methodologies used - more frequent application of "Concept Engineering" has a positive impact on "Formalising the NPD Process" (corrcoef $r=0.312$ );

- engineering, R\&D \& design tools/methodologies used - there is a moderate direct link between "Formalising the NPD Process" and "Value Analysis/Value Engineering" (corrcoef $r=0.332$ ), "Design for Manufacturing, Assembly, Testing" (corrcoef $r=0.412)$, "Parallel Engineering" (corrcoef $r=0.327$ );

- positive impact on "Formalising the NPD Process" have more frequent application of the following technology methods and tools: "Rapid Prototyping Systems" (corrcoef $r=0.321$ ), "Simulation Systems" (corrcoef $r=0.359)$, "Virtual 
Design" (corrcoef $r=0.333)$, "Product Data Management Systems" (corrcoef $r=0.380$ ), "Product Portfolio Management Software" (corrcoef $r=0.318$ ), "Web-Based Sourcing Management Software" (corrcoef $r=0.351$ ), "Configuration Management Systems" (corrcoef $r=0.420)$, "Project Management Systems" (corcoef $r=0.330)$, "Knowledge Management Systems" (corrcoef $r=0.357$ );

- in terms of management methods and tools, it has been found that more frequent application of "Dedicated project intranet" (corrcoef $r=0.307$ ) and "Groupware (software which allows group interaction)" (corrcoef $r=0.326$ ) has a positive impact on "Formalising the NPD Process".
The correlations of the dependent variable "Formalising the NPD process" and the independent variables that affect it have been shown in Figure 1.

\subsection{Regression analysis of the dependent variable "Formalising the NPD process"}

Regression analysis - the change in the dependent variable due to the change in the independent variable. Analysis of the dependent variable "Formalising the NPD process" has been carried out through applying standard multiple regression, the most widely applied type of regression

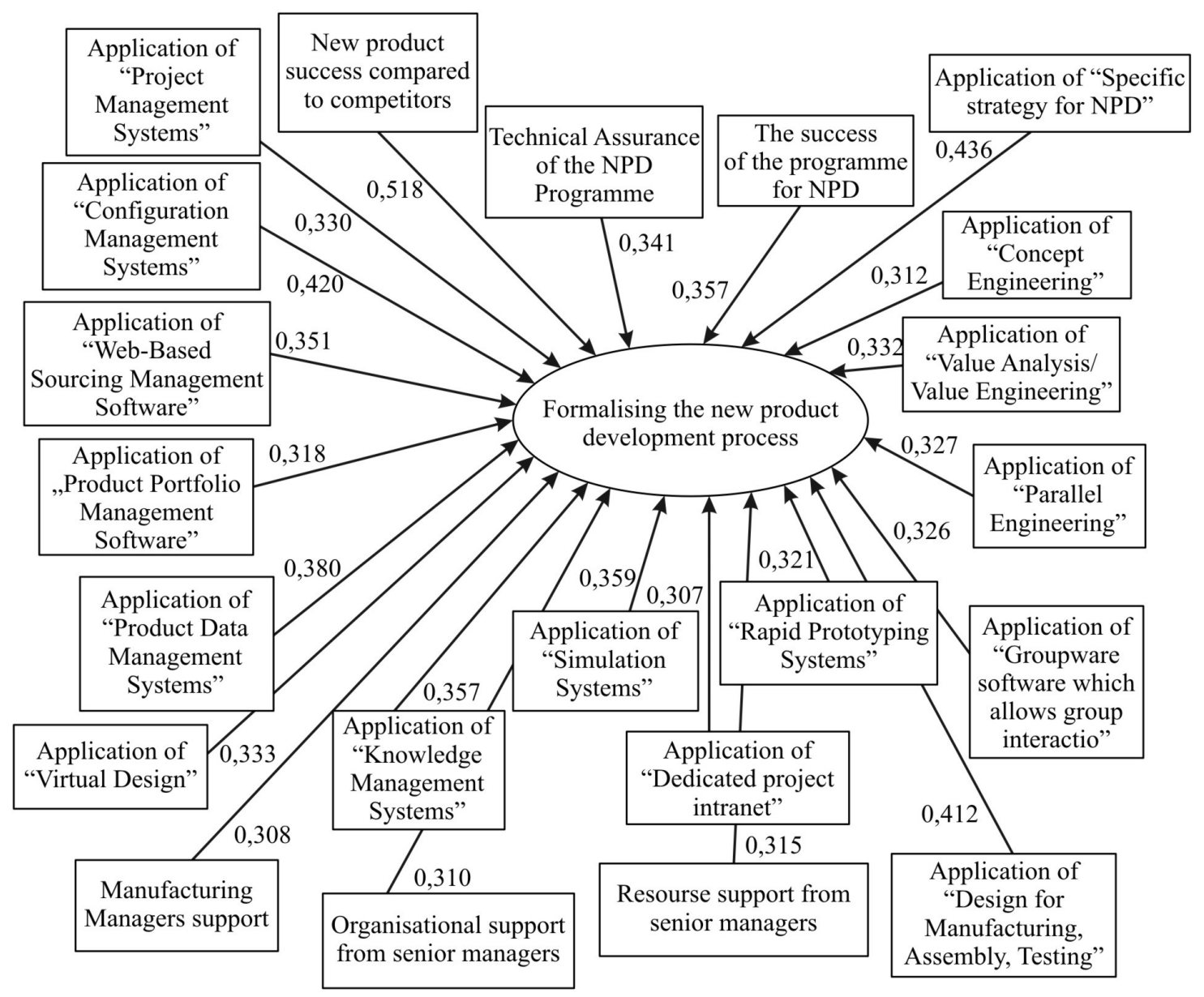

Source: own survey results

Figure 1. Factors affecting the formalising of NPD process 
analysis that is used. The following stages characterise the regression analysis (Pallant, 2005; Tabachnik \& Fidell, 2006): Stage 1: Checking the adequacy of the model; Stage 2: Evaluation of the model and Stage 3: Evaluation of each independent variable of the model.

When factor variables are selected the following limitations are considered: (1) factor variables with correlation coefficient $r>0.3$ are included. (2) for avoiding multicollinearity between independent variables, the one that is in a weaker correlation dependence with the dependent variable studied is not included.

Regression analysis of the dependent variable "Formalising the NPD process".

- Stage 1: Checking the adequacy of the model (Table 1.). In the analysis, 19 independent variables are subjected to investigation of their common and individual contribution to forming the dependent variable: (1) New product success compared to competitors; (2) The success of the programme for NPD; (3) Application of "specific strategy for new product activities that directs and integrates the entire new product programme"; (4) Manufacturing "Managers support innovation by ensuring that their people participate actively and effectively in teams"; (5) Senior managers support innovation by making sure that available resources flow smoothly to innovation projects; (6) Application of "Concept Engineering"; (7) Application of "Value Analysis/Value Engineering"; (8) Application of "Design for Manufacturing, Assembly, Testing"; (9) Application of "Parallel Engineering"; (10) Application of "Simulation Systems"; (11) Application of "Virtual Design", (12) Application of "Product Data Management Systems"; (13) Application of "Product Portfolio Management Software"; (14) Application of "Web-Based Sourcing Management Software"; (15) Application of "Configuration Management Systems" (16) Application of "Project Management Systems"; (17) Application of "Knowledge Management Systems"; (18) Application of "Dedicated project intranet"; (19) Application of "Groupware (software which allows group interaction".

The values obtained for all indexes, assessing the adequacy of the regression are in the admissible intervals. Hence, it can be concluded that the regression model of the dependent variable "Formalising the NPD process" confirms the adequacy requirement.

Table 1. Criteria, determining the adequacy of the regression model of the dependent variable "Formalising the NPD process"

\begin{tabular}{|c|c|c|c|}
\hline $\begin{array}{l}\text { Adequacy criterion of } \\
\text { the model }\end{array}$ & Measurement & Study data & Reference values \\
\hline Multicollinearity & Correlation coefficient & Max. $r=0.670$ & $\mathrm{R}<0.7$ \\
\hline \multirow[t]{2}{*}{ Collinearity } & Tolerance & Min. Tolerance $=0.258$ & Tolerance $>0.1$ \\
\hline & VIF & Max. VIF = 3.881 & $\mathrm{VIF}<10$ \\
\hline $\begin{array}{l}\text { Deviation from the mean } \\
\text { values }\end{array}$ & Std. Residual & $\begin{array}{l}\text { Mean Std. Residual = } \\
0.000\end{array}$ & $-3<$ Std. Residual $<+3$ \\
\hline Normality & Cook's Distance & $\begin{array}{l}\text { Mean Cook's Distance } \\
=0.005\end{array}$ & Cook's Distance<1 \\
\hline Linearity & Graphics & $\begin{array}{l}\text { There is linearity } \\
\text { (Figure 2) }\end{array}$ & $\begin{array}{l}\text { Diagonal position along } \\
\text { a straight line }\end{array}$ \\
\hline
\end{tabular}

Source: own survey results 
Normal P-P Plot of regression Standardized Residual, Dependent variable: "Formalising the NPD process"

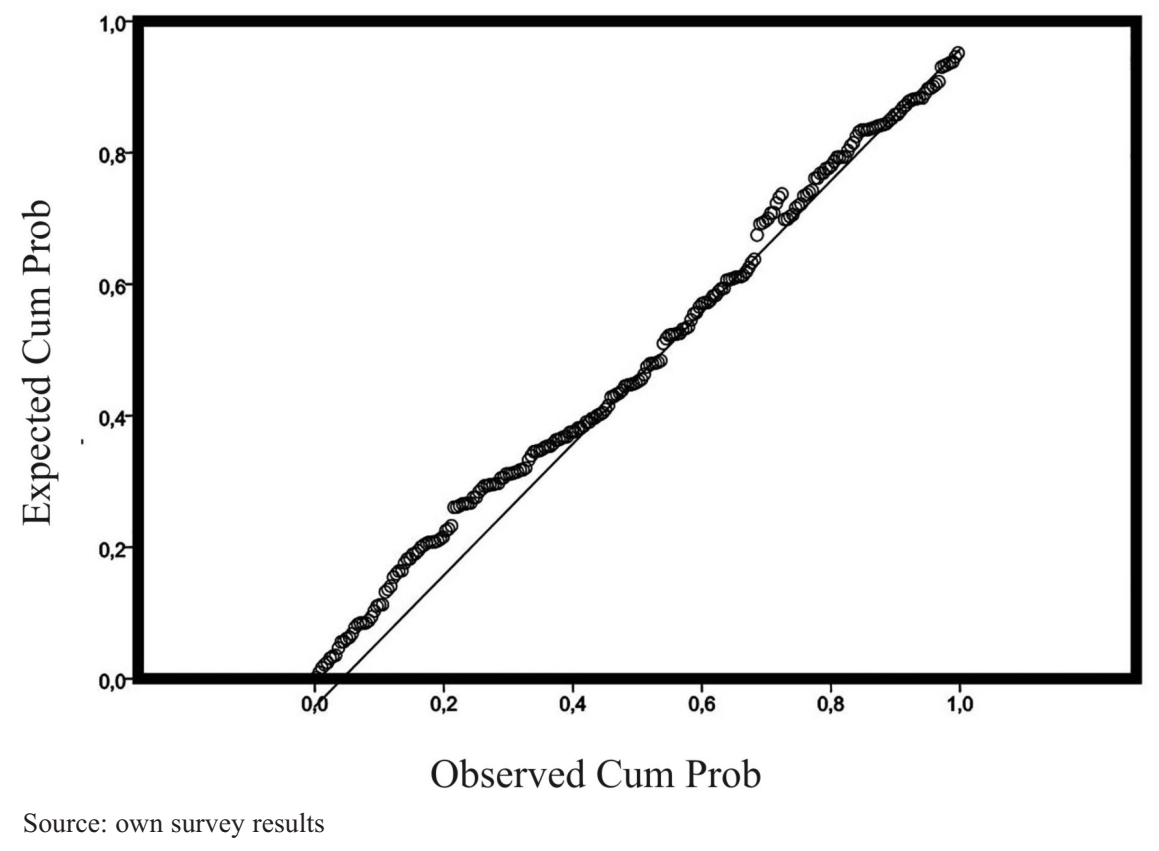

Figure 2. Linear correlation between the independent variables trial values and the dependent variable "Formalising the NPD process"

- Stage 2: Evaluation of the model. The index R Square in the model explains $47 \%$ of the variation of the dependent variable studied. The value of Adjusted R Square shows that $42.30 \%$ of the dependent variable change are due to the independent variables, included in the regression model (Table 2.).

The model is statistically significant, according to the index value Sig. $=0.000$, since it is under the tolerable statistical error of $5 \%$ (absolute value 0.05 ), determined for such studies.

- Stage 3: Evaluation of the independent variables in the model. The standar-dised
Beta coefficients in absolute values show that the factors that have the strongest contribution on the dependable variable are: success of new products compared to that of competitors (-0.306); applying a strategy that directs and integrates the entire NPD process (-0.284); applying "production design, assembly and testing" (0.226); applying "systems for configuration management" (0.148) and applying "a system for product data management" (0.120). The first three factors demonstrating a unique statistically significant contribution since $\operatorname{sig}<0.05$. A summarized evaluation of the model and the individual impacts on the

Table 2. Indexes for evaluation of the regression model of the dependent variable "Formalising the NPD process"

\begin{tabular}{lccccc}
\hline Dependent variable & R & R Square & Adjusted R Square & \% & Sig. \\
\hline Formalising the process of NPD & .686 & .470 & .423 & 42.30 & 0.002 \\
\hline Source: own survey results & & & & &
\end{tabular}


Table 3. Indexes for evaluation of the independent variables in the regression mode of the dependent variable "Formalising the NPD process"

\begin{tabular}{|c|c|c|c|c|c|}
\hline Factor variables & $\begin{array}{c}\text { Standardised } \\
\text { coefficients } \\
\text { Beta }(\beta)\end{array}$ & Sig & Part & $\begin{array}{c}\text { Part } \\
\text { Square }\end{array}$ & $\begin{array}{c}\text { Part } \\
\text { Square*100 } \\
(\%)\end{array}$ \\
\hline $\begin{array}{l}\text { New product success compared to } \\
\text { competitors }\end{array}$ & .306 & .000 & .205 & 0.04203 & 4.20 \\
\hline The success of the programme for NPD & -.013 & .845 & -.010 & 0.0001 & 0.01 \\
\hline $\begin{array}{l}\text { Application of specific strategy for new } \\
\text { product activities that directs and } \\
\text { integrates the entire new product } \\
\text { programme }\end{array}$ & .284 & .000 & .249 & 0.062 & 6.20 \\
\hline $\begin{array}{l}\text { Manufacturing Managers support } \\
\text { innovation }\end{array}$ & .032 & .625 & .024 & 0.00058 & 0.06 \\
\hline $\begin{array}{l}\text { Senior managers support innovation by } \\
\text { making sure that available resources } \\
\text { flow smoothly to innovation projects }\end{array}$ & -.068 & .335 & -.048 & 0.00234 & 0.23 \\
\hline Application of "Concept Engineering" & .002 & .982 & .001 & 0.000001 & 0.00 \\
\hline $\begin{array}{l}\text { Application of "Value Analysis/Value } \\
\text { Engineering" }\end{array}$ & -.006 & .939 & -.004 & 0.000016 & 0.00 \\
\hline $\begin{array}{l}\text { Application of "Design for } \\
\text { Manufacturing, Assembly, Testing", }\end{array}$ & .226 & .005 & .143 & 0.02045 & 2.05 \\
\hline Application of "Parallel Engineering" & -.029 & .700 & -.019 & 0.00036 & 0.04 \\
\hline Application of "Simulation Systems" & .030 & .688 & .020 & 0.0004 & 0.04 \\
\hline Application of "Virtual Design" & .047 & .522 & .032 & 0.00102 & 0.10 \\
\hline $\begin{array}{l}\text { Application of "Product Data } \\
\text { Management Systems" }\end{array}$ & .120 & .109 & .080 & 0.0064 & 0.64 \\
\hline $\begin{array}{l}\text { Application of "Product Portfolio } \\
\text { Management Software" }\end{array}$ & -.045 & .581 & -.027 & 0.00073 & 0.07 \\
\hline $\begin{array}{l}\text { Application of "Web-Based Sourcing } \\
\text { Management Software" }\end{array}$ & .011 & .889 & .007 & 0.00005 & 0.01 \\
\hline $\begin{array}{l}\text { Application of "Configuration } \\
\text { Management Systems" }\end{array}$ & .148 & .132 & .075 & 0.00563 & 0.56 \\
\hline $\begin{array}{l}\text { Application of "Project Management } \\
\text { Systems" }\end{array}$ & -.075 & .355 & -.046 & 0.002112 & 0.21 \\
\hline $\begin{array}{l}\text { Application of "Knowledge Management } \\
\text { Systems" }\end{array}$ & .024 & .723 & .018 & 0.00032 & 0.03 \\
\hline $\begin{array}{l}\text { Application of "Dedicated project } \\
\text { intranet" }\end{array}$ & .007 & .922 & .005 & 0.00003 & 0.00 \\
\hline $\begin{array}{l}\text { Application of "Groupware (software } \\
\text { which allows group interaction)" }\end{array}$ & .036 & .628 & .024 & 0.00058 & 0.06 \\
\hline
\end{tabular}

Source: own survey results

dependable variable can be inferred from the results obtained for the coefficients Adjusted R Square and Part Square (Table 3.).

The total contribution of the independent variables for changing the dependent variable is $42.3 \%$. The sum value of the individual independent variables impacts is $14.51 \%$, which is less than the total contribution of the independent variables. The difference is due to the fact that the coefficient Part shows only the unique contribution of the independent variables, without taking into account their common impacts or mutual overlapping. The general or mutual influence of factors, included in the model, is equal to $27.79 \%$.

Individual influence on formalising the NPD process is made by the following factors which have been shown in Figure 3.

The analysis shows that there are many 


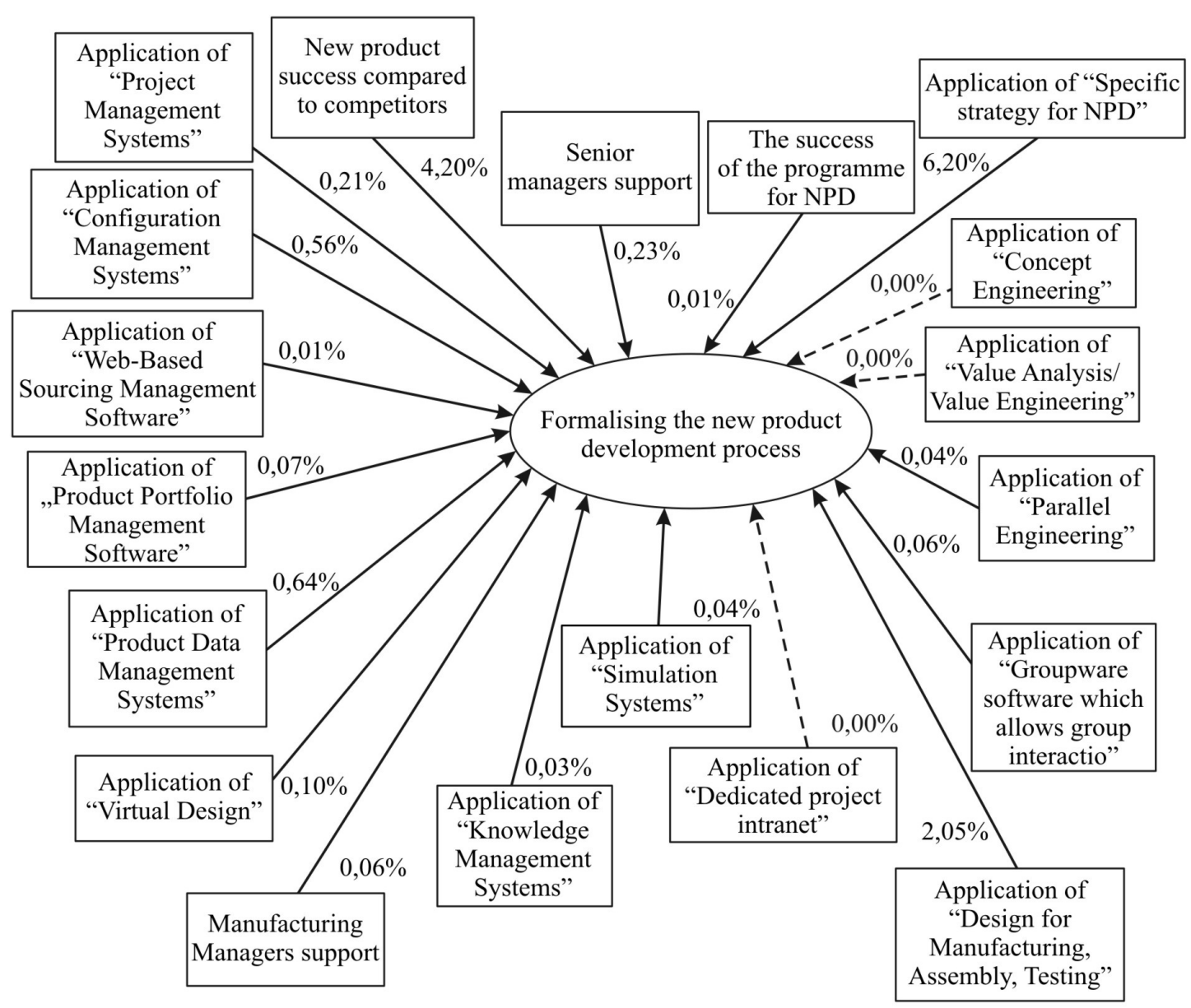

Note: the dotted lines mark factors, which have general, but not individual influence on the dependent variable Source: own survey results

Figure 3. Individual influence of various factors on the dependable variable "Formalising the NPD process"

factors influencing the formalisation of the new product development process. A number of inter-company factors have been identified that can be influenced for the successful NPD. In this respect, frequency of application of the above-mentioned factors should be subject to particular attention by managers.

\section{CONCLUSIONS}

1. High level of activity and interest among respondents to the study has been observed. Respondents have expressed their desire to readiness for further support and implementation of future contacts.

2. Formalising the NPD process depends directly on: the success of new products, compared to that of the competitors; the technical assistance and success of NPD programme; applying NPD strategy; practices employed for organising the NPD process (incl. applying different type of personalisation for project management; tactics employed for forming of project teams; degree of support by those leading the NPD process), as well as the marketing, 
research, design, technological and management methods and tools employed.

3. The total contribution of the independent variables for changing the dependent variable is $42.3 \%$. The sum value of the individual independent variables impacts is $14.51 \%$, which is less than the total contribution of the independent variables. The difference is due to the fact that the coefficient Part shows only the unique contribution of the independent variables, without taking into account their common impact or mutual overlapping. The general or mutual influence of factors, included in the model, is equal to $27.79 \%$.

4. The use of officially documented procedures is an imperative. The importance of formalizing the NPD process and its effects has to be realized, as its application minimizes the risk of overlooking procedures in NPD and is a basis for learning experiences. All analytical factors influencing formalizing the NPD process should be subject to particular attention by the managers. They should enhance the frequency of application of the above mentioned factors with a view of improving the management level in the development of product innovations.

\section{References}

Al-Shalabi, A., Omar, M., \& Rundquist, J. (2008). Processes and strategies of NPD: a survey of Malaysian industry. International Journal of Manufacturing Science and Technology, 10 (1), 91-95.

Al-Shalabi, A., \& Rundquist, J. (2010). Outsourcing organizing NPD at emerging markets: a survey of Malaysian firms. International Journal of Business and Emerging Markets, 2 (3), 213-234.
Albers, A., Gladysz, B., Heitger, N., \& Wilmsen, M. (2016). Categories of product innovations - a prospective categorization framework for innovation projects in early development phases based on empirical data. Procedia CIRP, 50, 135-140.

Akgün, A., Dayan, M., \& Benedetto, A. (2008). New product development team intelligence: antecedents and consequences. Information \& Management, 45, 221-226.

Artto, K., \& Kulvik, I. (2011). The integrative role of project management office in the front end of innovation. International Journal of Project Management, 29, 408421.

Barczak, G., Griffin, A., \& Kahn, K. (2009). Perspective: Trends and drivers of success in NPD practices: results of the 2003 PDMA best practices study. The Journal of Product Innovation Management, 26, 3-23.

Belliveau, P., Griffin, A., \& Somermeyer, St. (2002). The PDMA toolbook for new product development. New York: John Wiley \& Sons.

Chang, H., Tsai, M., \& Tsai, C. (2011). Complex organisational knowledge structures for new product development teams. Knowledge-Based Systems, 24, 652661.

Dickel D., \& Moura, G. (2016). Organisational performance evaluation in intangible criteria: a model based on knowledge management and innovation management. RAI Revista de Administração e Inovação, 13 (3), 211-220.

Geissdoerfer, M., Savaget, P., \& Evans, S. (2017). The Cambridge business model innovation process. Procedia Manufacturing, 8, 262-269.

Griffin, A. (1997). PDMA research on new product development practices: updating trends and benchmarking best practices. The Journal of Product Innovation 


\title{
ИСТРАЖИВАЊЕ ИНТЕРАКЦИЈА ФАКТОРА У ФОРМАЛИЗАЦИЈИ ПРОЦЕСА РАЗВОЈА НОВИХ ПРОИЗВОДА
}

\author{
Bozhana Stoycheva, Diana Antonova
}

\section{Извод}

Креирање нових програма развоја производа у индустријским организацијама, као процес укључује системске активности за дефинисање, планирање и имплементацију пројеката, у циљу успешне тржишне реализације. Успех програма и његових повезаних пројеката није недвосмислен (у одређеној мери зависи од становишта учесника) и може се односити на постизање унапред утврђених циљева и ограничења, задовољства купаца, организационог знања итд. За одговарајућу индустријску компанију процес планирања је важнији од самог плана због чега су од значаја проверене хипотезе; анализиране упоредиве алтернативе; истражене будуће последице једне или друге данашње одлуке; као и извршене неопходне промене предуслова.

Истраживање представљено у овом раду је спроведено у 560 средњих и великих предузећа која послују у прерађивачкој индустрији у Бугарској. Циљ је успостављање независних факторских променљивих и њихов утицај на ефикасно управљање процесом развоја нових производа, које се односе на зависну променљиву "формализација или коришћење званично документованих поступака који описују процес развоја нових производа (РНП)".

Како би се постигли циљеви, спроведена је квантитативна студија применом корелационе и регресионе анализе, за тражење односа и зависности између испитиваних променљивих. Приказан је регресиони модел за истраживану зависну променљиву. Добијени резултати и препоруке могу се користити за побољшање управљања процесом иновација производа.

Кључне речи: иновацијски процес, развој нових производа, формализација РНП, факторска анализа

Management, 14, 429-458.

Hong, P., \& Roh, J. (2009). Internationalization, product development and performance outcomes. A comparative study of 10 countries. Research in International Business and Finance, 23, 169180.

Kazmi, S., Naaranoja, M., Kytola, J., \& Kantola, J. (2016). Connecting strategic thinking with product innovativeness to reinforce NPD support process. Procedia Social and Behavioral Sciences, 235, 672684.

Kim, B., \& Kim, J. (2009). Structural factors of NPD (new product development) team for manufacturability. International Journal of Project Management, 27, 690702.

Kohl, H., Orth, R., Riebartsch, O., \& Hecklau, F. (2016). Integrated evaluation system for the strategic management of innovation initiatives in manufacturing industries. Procedia CIRP, 40, 335-340.

Kulatunga, A., Karunatilake, N., Weerasinghe, N., \& Ihalawatta, R. (2015). Sustainable manufacturing based decision support model for product design and development process. Procedia CIRP, 26, 8792.

Oliviera, M., \& Rozenfeld, H. (2010). 
Integrating technology roadmapping and portfolio management at the front-end of new product development. Technological Forecasting \& Social Change, 77, 13391354.

Pallant, J. (2005). "SPSS Survival Manual". A step by step guide to data analysis using SPSS for Windows (Version 12). Crows Nest, NSW, Australia : Allen \& Unwin.

Rametsteiner, E., \& Weiss, G. (2006). Innovation and innovation policy in forestry: linking innovation process with systems models. Forest Policy and Economics, 8, 691-703.

Riel, A., Neumann, M., \& Tichkiewitch, S. (2013). Structuring the early fuzzy frontend to manage ideation for new product development. CIRP Annals - Manufacturing Technology, 62, 107-110. 